\title{
Energy efficient way of processing waste of milk production
}

\author{
Julija Panfilova ${ }^{1 \mathrm{a}}$, Maria Ivantsova $^{1}$, and Irina Selezneva ${ }^{1}$ \\ ${ }^{1}$ Ural Federal University named after the first President of Russia B.N. Yeltsin, 620002, \\ Yekaterinburg, Russia
}

\begin{abstract}
The research aim is the search of practical application of biotechnological waste processing of dairy production plants. The result of the study is the development of a process with biogas production by using anaerobic Biomar reactor. Scale of laboratory installation has been conducted based on laboratory studies. Moreover, principal technological scheme of production has been composed, and the appropriate material and technical and economic calculations have been carried out. In addition, major production facilities have been picked up. We found that using the produced biogas as a fuel for the boiler system allows you to reduce the natural gas consumption and reduce the cost of the recycling process at the dairy industry plants.
\end{abstract}

Whey is the main waste of dairy industry. Whey contains high concentrations of organic pollutants (fat, protein and lactose), inorganic compounds, synthetic surfactants and bacteria. Their content can be greater than the maximum permissible value.

In this work the object of laboratory tests was "Danone" plants waste water which contains cheese whey. The daily volume of water is $9.9 \mathrm{~m}^{3}$. Cheese whey is a kind of whey which is colored liquid. The color varies from pale yellow to green. The chemical composition of cheese whey is shown in Table 1.

Table 1. The chemical composition of cheese whey

\begin{tabular}{|l|l|}
\hline Solids in \% & $4,2-7,4$ \\
\hline including: & \\
\hline lactose (carbohydrates) & 3.5 \\
\hline protein & $0.8-1.0$ \\
\hline milk fat & $0.05-0.4$ \\
\hline minerals & $0.5-0.8$ \\
\hline acidity, ${ }^{\circ} \mathrm{T}$ & $50-85$ \\
\hline density, $\mathrm{kg} / \mathrm{m}^{3}$ & $1019-1026$ \\
\hline $\mathrm{COC}, \mathrm{mg} / \mathrm{l}$ & 57100 \\
\hline
\end{tabular}

The whey composition also includes vitamins E, C, B, and biotin (B7, H, coenzyme Q) and choline (Vitamin B4). Whey contains valuable mineral salts of phosphorus, magnesium and calcium.

\footnotetext{
a Corresponding author: Yusyaaaa@rambler.ru
} 
Wastewater treatment methods are divided into mechanical, physical, chemical and biological ones. Biological methods of wastewater treatment are based on microorganisms that mineralize dissolved organic compounds, which are a power source for microorganisms.

Anaerobic decomposition of organic substances is carried out by the microorganisms' community that makes up the food chain of primary and secondary anaerobes. In contrast to the trophic chains of microorganisms in aerobic processes, where the relationships between groups of organisms are mainly characterized by relations "predator - prey", methane fermentation for trophic systems is characterized by the use of some groups of bacteria exchange products by the other ones.

Anaerobic methane fermentation involves four steps:

1. Step of enzymatic hydrolysis of undissolved complex organic compounds to formation of simpler dissolved substances;

2. Step of acid formation with the release of short chain volatile fatty acids (VFA), amino acids, alcohols and hydrogen and carbon dioxide (acidgenic step);

3. Acetogenic step of conversion of VFA, alcohols and amino acids into acetic acid, dissociating into hydrogen cation and acetate anion;

4. Methanogenic stage which is the formation of methane from acetic acid, as a result of the reduction reaction of carbon dioxide by hydrogen.

Five groups of bacteria involve in the process of anaerobic fermentation. The first group includes fermentative bacteria, represented mainly by Bacillus, Micrococcus, Pseudomonas and Clostridium, realizing the step of enzymatic hydrolysis and acid formation. Almost all of these bacteria are referred to growing facultative anaerobes with an optimum $\mathrm{pH}$ 6.5-7.6. Bacteria isolate biological catalysts called exoenzymes, which help realize the hydrolysis and transfer of solid insoluble compounds into the dissolved state. The rate of hydrolysis depends on the nature of the organic substances and of its conditions: namely it is necessary to provide sufficient enzyme amounts, create conditions for their contact with an organic substrate, support temperature and optimum $\mathrm{pH}$.

Acidgenic step is carried out by the above heterogeneous groups of microorganisms for which carbon having passed into the solution of simple substances is a source of power. $20 \%$ of the original substances of original waste are converted into acetic acid, $15 \%$ are converted into propionic acid, and $65 \%$ are converted into other intermediates. Step of acid formation does not limit the subsequent steps of fermentation, because bacteria are unpretentious and grow at a high speed. However, actively proceeding steps hydrolysis and acid formation can lead to accumulation of volatile acid and decrease the $\mathrm{pH}$, which is the direct cause of inhibiting the bacteria growth of subsequent process steps [1].

Acetogenic step is carried out by two groups of acetogenic bacteria. The first group forms acetate with hydrogen evolution (acetogens forming hydrogen are the second group) from the soluble product of the preceding step of acid formation:

$$
\begin{aligned}
& \mathrm{CH}_{3} \mathrm{CH}_{2} \mathrm{COOH}+2 \mathrm{H}_{2} \mathrm{O} \rightarrow \mathrm{CH}_{3} \mathrm{COOH}+\mathrm{CO}_{2}+3 \mathrm{H}_{2} . \\
& \mathrm{CH}_{3} \mathrm{CH}_{2} \mathrm{CH}_{2} \mathrm{COOH}+2 \mathrm{H}_{2} \mathrm{O} \rightarrow 2 \mathrm{CH}_{3} \mathrm{COOH}+2 \mathrm{H}_{2} .
\end{aligned}
$$

The second group of acetogenic bacteria leads to the formation of acetic acid by the use of hydrogen for $\mathrm{CO} 2$ recovery (acetogens using hydrogen are the third group):

$$
4 \mathrm{H}_{2}+2 \mathrm{CO}_{2} \rightarrow \mathrm{CH}_{3} \mathrm{COOH}+2 \mathrm{H}_{2} \mathrm{O} \text {. }
$$

At the fourth methanogenic step, methane bacteria produce methane in two ways namely by splitting acetate (a fifth group of bacteria) and reduction of carbon dioxide by hydrogen (a fourth group of bacteria). 


$$
\begin{aligned}
& \mathrm{CH}_{3} \mathrm{COOH} \rightarrow \mathrm{CH}_{4}+\mathrm{CO}_{2}\left(72 \% \mathrm{CH}_{4}\right) \\
& \mathrm{CO}_{2}+\mathrm{H}_{2} \rightarrow \mathrm{CH}_{4}+\mathrm{H}_{2} \mathrm{O}\left(28 \% \mathrm{CH}_{4}\right) .
\end{aligned}
$$

5 major groups of methane bacteria namely Methanococcus, Methanobacterium, Methanospirillum, Methanotrix and Methanosarcina can be involved in the process. Methane bacteria are strict anaerobes.

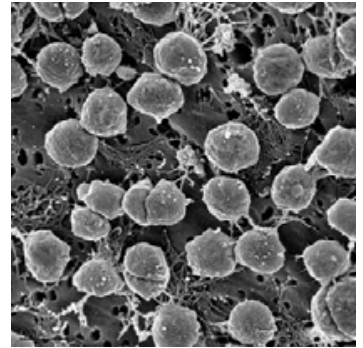

Fig. 1. Methanococcus jannischii.

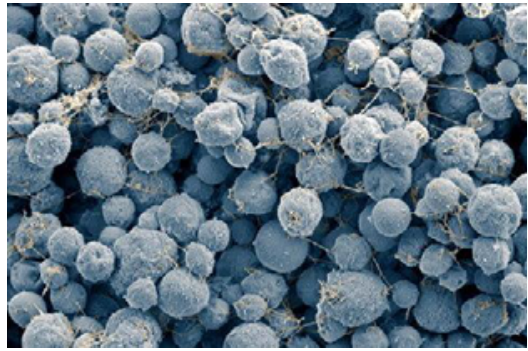

Fig. 2. Methanosarcina archaea.

They are very sensitive to the presence of dissolved oxygen and nitrates in the medium. Optimum $\mathrm{pH}$ for them is 7.0-7.5. Carbon sources for methane bacteria are acetate ion and carbon dioxide. The energy source is hydrogen and the main source of nitrogen is ammonia. The main sulfur source is sulphides, although cysteine and sulfates can be the source too. Methanogens also need various trace elements $(\mathrm{K}, \mathrm{Na}, \mathrm{Mg}, \mathrm{Co}, \mathrm{Cu}, \mathrm{B}, \mathrm{Zn}$, Mo).

Methane fermentation should always consider not individual groups of bacteria, but the entire community as a whole. The efficiency of fermentation process in such a community of bacteria does not only depend on the activity of the organisms involved in the reaction, but on the vital functions of bacteria that consume the products of this reaction. The accumulation of metabolic products of one of the process steps leads to the inhibition of others. Bacteria at different steps have their morphological and physiological characteristics, expressed in different growth rates, sensitivity to $\mathrm{pH}$ and $\mathrm{O} 2$ and others. All of these factors play a major role in creating a well-balanced and wellworking system [2].

BIOMAR anaerobic treatment facilities are encouraged to use for organizing the biological wastewater treatment process in the dairy industry (Figure 1). Qualitative averaging of waste water is due to a specially calculated volume in the mixer. Sharp fluctuations in $\mathrm{pH}$ are naturally smoothed out, uneven receipt for cleaning drains is prevented. Another important function of the averager is the biological pre-oxidation of organic substances in the waste water. Duration of the water presence in the neutralizer for pre-oxidation was calculated based on the degree of contamination. 


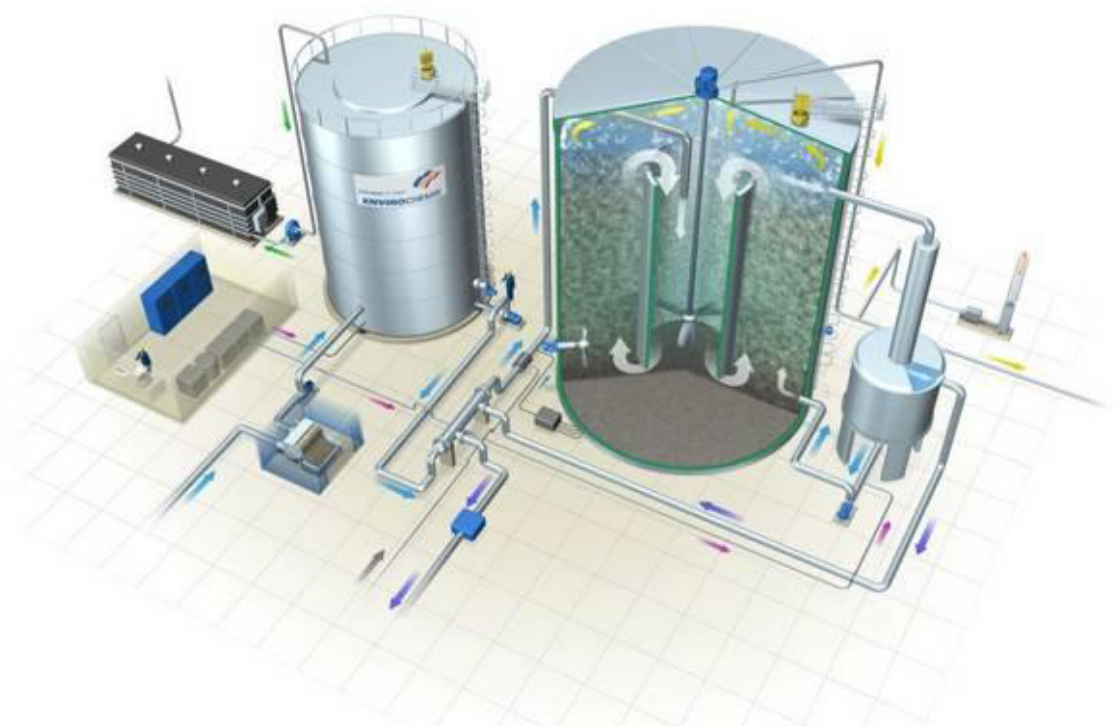

Fig. 3. Biomar ALB: anaerobic method using upflow reactor.

Before the wastewater gets into the anaerobic Biomar reactor, its optimal parameters ( $\mathrm{pH}=7.2-7.4$ and $\mathrm{T}=37^{\circ} \mathrm{C}$ ) are set automatically [1]. It should be noted that the use of the Biomar reactor will increase the performance of treatment facilities, improve the quality of waste water treatment and reduce the amount of excess sludge.

Another important advantage of Biomar reactor is a little need for production facilities, which allows the reconstruction of the existing plants.

Sediments are produced in the process of wastewater treatment. These sediments are subject to decontamination, disinfection, dehydration and drying. In addition, subsequent disposal of sediments is possible. Sediments contain significant amounts of fertilizing macro- and micronutrients, especially nitrogen, phosphorus and potassium. Moreover, the sediment includes zinc, manganese, copper, molybdenum and others. Sediments are usually utilized after their dehydration.

Dehydration of digested sediment is carried out with the help of mechanical apparatus namely vacuum filters, centrifuges, filter presses of different types, and drying in natural conditions in the sludge beds [3]. Digested sediment has high moisture content (95-98\%), which makes it difficult to use it in agriculture. Humidity is the main factor determining the amount of sediment. Therefore, the main aim of sediment treatment is to reduce its volume due to water separation and production of a transportable product.

To solve these problems we have proposed a system of buildings and equipment for the anaerobic treatment of waste water and sediment treatment, which includes:

1) methane tank for anaerobic digestion;

2) the absorber to trap hydrogen sulfide;

3) gas tank for collecting the evolved biogas;

4) centrifuge for dehydration of digested sediment;

5) the dryer for driving sediment into a form suitable for transportation and later use. 


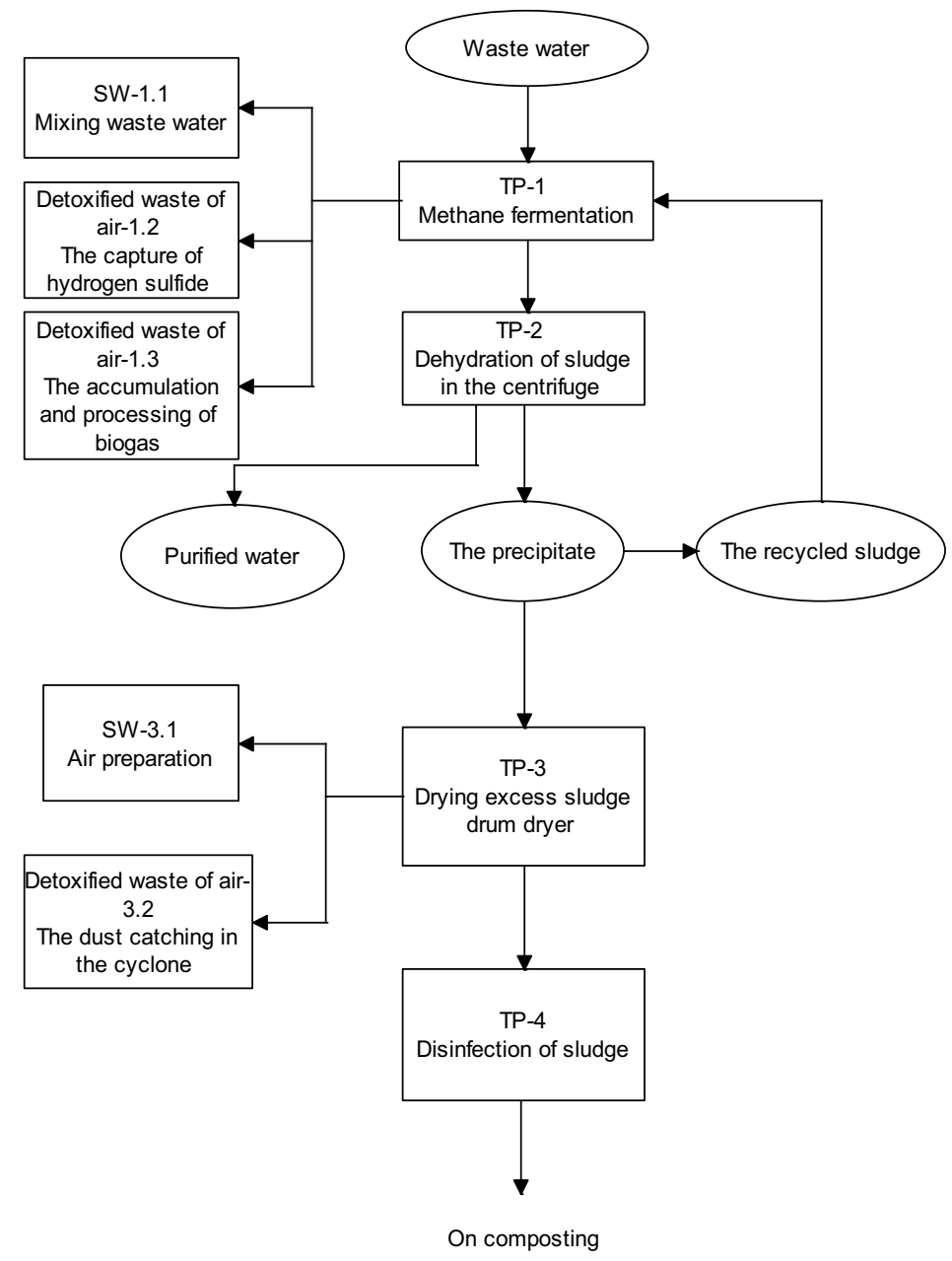

Fig. 4. Technological scheme of the process of wastewater treatment and disinfection of sediment

Along with the biogas, hydrogen sulfide is released during the methane fermentation, which is caught by monoethanolamine solution in the absorber of plate type. The cleaned gas from the absorber is collected in the gas holder. The saturated solution from the absorber after passing a heat transfer apparatus is sent to a desorber (distillation column) of packed or plate-type, where regeneration of monoethanolamine occurs.

$$
\begin{gathered}
\mathrm{HOCH}_{2} \mathrm{CH}_{2} \mathrm{NH}_{2}+\mathrm{H}_{2} \mathrm{~S} \rightleftharpoons\left(\mathrm{HOCH}_{2} \mathrm{CH}_{2} \mathrm{NH}_{3}\right)_{2} \mathrm{~S} \\
\left(\mathrm{HOCH}_{2} \mathrm{CH}_{2} \mathrm{NH}_{3}\right)_{2} \mathrm{~S}+\mathrm{H}_{2} \mathrm{~S} \rightleftharpoons 2 \mathrm{HOCH}_{2} \mathrm{CH}_{2} \mathrm{NH}_{3} \mathrm{HS} \\
\mathrm{HOCH}_{2} \mathrm{CH}_{2} \mathrm{NH}_{2}+\mathrm{CO}_{2}+\mathrm{H}_{2} \mathrm{O} \\
\left(\mathrm{HOCH}_{2} \mathrm{CH}_{2} \mathrm{NH}_{3}\right) \mathrm{HCO}_{3}
\end{gathered}
$$

The product of designed technological process is purified waste water. The main indicators of treated waste water quality are shown in Table 2.

Table 2. Indicators of treated wastewater

\begin{tabular}{|c|c|}
\hline \multicolumn{1}{|c|}{ Display } & Content in the purified waste water \\
\hline Phosphates $\mathrm{mg} / \mathrm{l}$ & 3,5 \\
\hline
\end{tabular}




\begin{tabular}{|l|c|}
\hline Ammonium nitrogen, $\mathrm{mg} / \mathrm{l}$ & 1,5 \\
\hline $\mathrm{pH}$ & 7,3 \\
\hline
\end{tabular}

A byproduct of milk production wastewater is biogas that is reasonably expected to use as a fuel. Natural gas consumption will be decreased by using the generated biogas (we calculated that the daily volume of the methane formed is $70 \mathrm{~m}^{3}$ ). The cost of natural gas consumed by plants is $4,011 \mathrm{rub} / \mathrm{m}^{3}$. Calorific values of natural gas and methane respectively are $39800 \mathrm{~kJ} / \mathrm{mol}$ and $40,000 \mathrm{~kJ} / \mathrm{mol}$. Technical and economic calculations have shown that annual savings from the use of biogas methane as a fuel instead of natural gas will amount to 100 thousand Rub.

It is possible to achieve the values of the monitored parameters, which do not harm the environment and will help to send treated water to the urban waste treatment plants as a result of the projected system construction for cleaning waste of the milk production.

Thus, it can be concluded that the biological anaerobic technology of wastewater treatment has lower operating costs compared to other methods. Moreover, the use of biogas would reduce the steam or electricity consumption by $10-15 \%$.

\section{References}

1. L.I. Gunther, L.L. Goldfarb, Methane-tanks (1991)

2. L. Gunther, Urban sewerage: Collection of scientific papers, VI, 158-170 (1961)

3. M. Chebotaeva, Wastewater treatment: trans. from germ (2013) 